\title{
Incinerarea - o posibilă provocare moral- pastorală contemporană pentru diaspora ortodoxă, în contextul unei culturi occidentale thanatofobe ${ }^{*}$
}

\author{
Gabriel NOJE ${ }^{* *}$
}

\begin{abstract}
Incineration - A Possible Contemporary Moral and Pastoral Challenge for the Orthodox Diaspora, in the Context of a Thanatophobic Western Culture. The European cultural and social context in which many Romanians that have left in search of a better life live is often full of moral and spiritual challenges. One of these challenges is the phenomenon of cremation or burning of the body
\end{abstract} after death. The secularized mentality of Western European society, the break with or alienation of ecclesial life and the forgetfulness of one's own Christian faith teachings can certainly be factors that make it easier for the Orthodox Christian living in the European diaspora to opt for the "solution” of cremation. For this reason, even if we do not have at hand statistical data on how often priests in the diaspora face dillemas of their faithful related to cremation, we believe that the presentation of this phenomenon and its analysis deserves all attention, given its extent in recent decades. Therefore, the aim of this study is rather prophylactic, preventive, trying to clarify some of the reasons why the Orthodox Church practices the burial of the body after death. The present study aims to discuss the issue of cremation on three levels. The first level presents the the way in which the phenomenon of burning the body is perceived nowadays. This is why it brings into discussion the positions and the opinions of sociologists and theologians

* Studiul de față are la bază cercetarea realizată în cadrul proiectului „Religie, politică şi drepturile omului", finanțat de Fundația Diatheke, Cluj-Napoca, printr-o bursă doctorală privată pentru anul 2017-2018.

*** Doctor în Teologie al Facultății de Teologie Ortodoxă, Universitatea BabeşBolyai din Cluj-Napoca, România. 
regarding the reality and the spreading of the phenomenon of cremation. The second level focuses briefly on how the Christian Churches have responded to the issue of cremation. Finally, the third level highlights the arguments for which the Orthodox Church opposes the burning of the bodies of the deceased people.

Keywords: cremation, body, contemporary moral challenge, soul and body relation, Old Testament, New Testament, funeral practice, burial.

\section{Preliminarii}

Contextul cultural occidental în care trăiesc mulți dintre românii plecați în căutarea unui trai mai bun este adesea plin de provocări morale și spirituale. Una dintre aceste provocări o poate constitui fenomenul incinerării sau al arderii trupului după moarte. Mentalitatea secularizată a societății occidentale, ruperea sau înstrăinarea de viața eclezială și uitarea propriilor învățături de credință creștine pot reprezenta cu siguranță factori care să-1 determine pe creștinul ortodox trăitor în diaspora să opteze mai uşor pentru „soluția” incinerării. Din acest motiv, chiar dacă nu avem la îndemână date statistice referitoare la cât de des se confruntă preoții din diaspora cu dileme ale credincioșilor lor legate de incinerare, considerăm că prezentarea acestui fenomen și analizarea lui merită toată atenția, dată fiind amploarea lui în ultimele decenii. De aceea, scopul acestui studiu este unul mai degrabă profilactic, preventiv, încercând să lămurească câteva dintre motivele pentru care Biserica Ortodoxă practică înhumarea trupului.

În acest sens, studiul de față își propune să dezbată problema incinerării pe trei paliere. Primul palier prezintă maniera în care este perceput în zilele noastre fenomenul arderii trupului, aducând în discuție poziții și opinii ale sociologilor și ale teologilor vizavi de realitatea și răspândirea fenomenului incinerării. Al doilea palier se concentrează succint pe modul în care Bisericile creștine au răspuns problematicii incinerării. În sfârşit, cel de-al treilea palier evidențiază care sunt argumentele pentru care Biserica Ortodoxă se opune arderii trupurilor celor decedați. 


\section{Incinerarea, astăzi: de la grija față de mediu la oroarea față de trupul neînsuflețit}

Departe de a fi un fenomen cu totul nou în istoria umanității ${ }^{1}$, și după multe secole în care a fost interzisă în creștinismul occidental, fiind considerată un obicei idolatru, păgân, practica incinerării se dovedește a fi astăzi, conform statisticilor ${ }^{2}$, pentru tot mai mulți dintre europeni ${ }^{3}$

${ }^{1}$ Alături de înhumare, incinerarea a fost atestată istoric ca practică funerară încă din cele mai vechi timpuri. Oferim câteva exemple. Incinerarea a fost practicată în Grecia Antică, concomitent cu înhumarea, începând cu epoca bronzului și până în jurul anului 480 î. Hr., când înhumarea devine practica de înmormântare dominantă. Vezi pentru mai multe detalii articolul lui O. T. P. K. DicKInson, „Ancient Greece”, în Douglas J. DAvIES, Lewis H. MATES (eds.), Encyclopedia of Cremation, Printed in Great Britain, Ashgate, 2005, p. 6-7. Vezi, de asemenea, și observația lui Erwin RoHde, Psyché, trad. Mircea Popescu, Editura Meridiane, București, 1985, p. 41: „«Epoca incinerării» a fost precedată şi la greci de o epocă care, ca şi la perşi, indieni şi germani, morții erau înmormântați întregi”. În Marea Britanie există dovezi arheologice potrivit cărora incinerarea a fost practicată din perioada neoliticului (mileniile IV-III î. Hr.) până în perioada saxonă (410-650 d. Hr.) și că, vreme de mai bine de două milenii, a reprezentat ritul funerar prin excelență. A se vedea Jacqueline I. MCKinley, „Archaeology of Britain. Antiquity. Bronze Age”, în Douglas J. DAvies, Lewis H. MATES (eds.), Encyclopedia of Cremation, p. 9-15. Doctrine religioase, precum budismul sau hinduismul acordă o mare importanță practicii arderii trupurilor morților. De pildă, în hinduism incinerarea reprezintă mai mult decât un rit funerar social; ea simbolizează un sacrificiu de sine, fiind percepută ca un act al creației și al fecundității. Vezi, în acest sens, Mariana CAIXEIRO, „Antiesthi: traditional hindu cremation”, în Douglas J. DAvIES, LEWIS H. MATES (eds.), Encyclopedia of Cremation,..., p. 234-235. În Orientul Îndepărtat, practica arderii trupului defuncților poate fi întâlnită în India și Nepal din timpurile cele mai vechi până astăzi. Vezi în această direcție Gilles GRÉVIN, „Apport archéologique et médico-légal de l'étude de la crémation sur brûcher en Inde et au Népal", în Études sur la Mort, 132, 2/2007, p. 23-28.

${ }^{2} \mathrm{Ne}$ oprim în continuare la trei țări ale continentului european pentru a ilustra afirmația noastră. Este vorba de Belgia, Cehia și Franța, unde practica incinerării este foarte populară. Vom evalua evoluția incinerării luând ca punct de referinţă anii 2007 și 2017. Astfel, în Belgia în anul 2007 din 100.658 decese, 45.663 au fost incinerări, adică 45,36 \% din numărul total de decese. În 2017, tot în Belgia din 108.666 decese, 65.221 au fost incinerări, adică 60,02\% din numărul total de decese. O situație similară întâlnim și în Cehia. În 2007 din 104.636 decese, 83.572 au fost incinerări, adică un procentaj de 79,87 din totalul deceselor, în timp ce în 2017 din 111.443 decese, 92.578 au fost 
opțiunea funerară preferată în ceea ce privește soarta trupului lor după încetarea din viață. Tehnic vorbind, incinerarea sau cremațiunea ${ }^{4}$ este procedeul care constă în arderea trupului mort la o temperatură de peste 800 de grade Celsius, timp de cel puțin 90 de minute, după care urmează depunerea cenușii obținute într-o urnă specială 5 .

Studiile de sociologie a problemei morții oferă mai multe explicații revirimentului acestei practici funerare în vremurile noastre. Astfel, una dintre cauzele optării oamenilor pentru incinerare în detrimentul înhumării ține în mod evident de mentalitatea seculară, de caracterul secular al societății occidentale 6 . Din această perspectivă, este tot mai cert că secularizarea, acest proces continuu de negare a credinței revelate și de emancipare a individului de sub autoritatea spirituală a Bisericii, a condus treptat atât la o restructurare a concepției omului asupra vieții, principiilor și valorilor morale, cât și, implicit, la

incinerări, adică 83,07\% din totalul deceselor. În Franța în anul 2007 au fost înregistrate 519.100 decese din care 141.862 au fost incinerări, adică doar 27,33\% din numărul total al deceselor. În 2017 din 603.000 decese, $221.830 \mathrm{au}$ fost incinerări, reprezentând $36.79 \%$ din numărul total al deceselor, și, totuși, puțin mai mic față de anul 2016, când procentajul incinerărilor a fost de $39,51 \%$. Confruntând aceste cifre putem ușor să deducem că avem de-a face cu o evoluție în ceea ce privește preferința europenilor pentru incinerare în defavoarea înhumării. Pentru mai multe detalii a se consulta pagina de internet a Societății de incinerare a Marii Britanii, https://www.cremation.org.uk /international-statistics-2007\# și https://www.cremation.org.uk/internationalstatistics-2017.

${ }^{3}$ Practica incinerării o găsim răspândită și pe continentul nord-american și în Asia. Însă, pentru analiza noastră ne rezumăm doar la exemplele din Europa. Considerațiile pe care le exprimăm vizează cu precădere Europa Occidentală unde descreștinarea progresivă a societății face loc apariției și încetățenirii unor practici ce au fost interzise timp de decenii bune de Biserica Romano-Catolică, pe motiv că ar fi contrare principiilor de credință pe care le propovăduiește. $\mathrm{Cu}$ toate acestea, întrucât fenomenul incinerării se întâlnește și la noi în țară, aceste considerente sunt valabile și pentru țara noastră.

${ }^{4}$ Cuvântul cremațiune vine în limba română, pe filieră franceză, de la verbul latinesc cremare și înseamnă ,a arde” (Cf. Gheorghe DuȚu, Dicționar latinromân, București, Editura Humanitas, 2003, p. 308).

${ }^{5}$ Etapele acestui procedeu tehnic ni le descrie Joseph BERCHOUD, „La crémation”, în Études sur la Mort, 132, 2/2007, p. 105-107.

6 Vezi Marc MAYER, „Cremation et religion dans notre monde secularisé”, în Études sur la Mort, 132, 2/2007, p. 111. 
o schimbare a percepției și atitudinii umane asupra morții. Și, așa cum bine surprinde un autor, dacă sensul morții s-a schimbat în (post)modernitate, atunci s-au schimbat și funeraliile ${ }^{7}$. Așadar, faptul că un număr în creștere dintre locuitorii multor țări europene aleg ca trupul să le fie ars după moarte ar reprezenta o consecință a devalorizării semnificației morții în plan colectiv, dar și personal. Am putea spune, fără să greșim sau să exagerăm, că, privită din această perspectivă, incinerarea are de-a face cu un proces de secularizare sau laicizare a înseși ideii creștine de moarte.

Merită, ca o paranteză, și oarecum generalizând, să adăugăm aici că pentru mulți occidentali, până în epoca contemporană, credința în Dumnezeu și certitudinea existenței unei vieți dincolo de moarte au conferit fenomenului morții un sens precis, iar conștiinţa propriei morți şi a unei judecăți iminente imediat după aceasta în fața Judecătorului Suprem i-au determinat să-și raporteze constant faptele la imperativele evanghelice și să acționeze în conformitate cu acestea ${ }^{8}$. Insă, odată cu declinul evident al credinței iudeo-creștine într-un Dumnezeu personal și cu nașterea îndoielii cu privire la viața de dincolo, aceștia au pierdut sensul creștin, eshatologic, al morții și au văzut mai degrabă în aceasta, în moarte, finalul definitiv al vieții omului, decât un loc de tranzit, un prag către Dumnezeu. De aceea, probabil pentru mulți, dacă sfârșitul vieții este echivalent în zilele noastre doar cu moartea biologică a trupului, iar trupul - pentru o minte seculară - nu mai este hărăzit niciunui destin veșnic, atunci incinerarea ar apărea ca fiind perfect justificabilă şi acceptabilă rațional.

7 Vezi Michel Hanus, „La mort aujourd'hui”, în Études sur la Mort, 125 1/2004, p. 46-49.

8 Într-o carte dedicată raportului omului cu moartea, din perioada Evului Mediu și până în epoca noastră, istoricul Philippe Ariès arată că piederea treptată a credinței oamenilor în existența vieții de dincolo, în rai sau iad, a făcut loc apariției fenomenului incinerării. A se vedea Philippe ARIÈs, L'homme et la mort, coll. Univers historique, Paris, Éditions du Seuil, 1977, p. 570-571. O prezentare a sensului creștin al morții, din perspectiva tradiției răsăritene, gășim la Ștefan ILOAIE, „Taina morții ca taină a vieții. Atitudinea creștinului față de moarte", în Tabor, 6/2007, p. 5-9. Remarcabilă este în privința subiectului amintit și cartea lui Filoteu FAros, Moartea și doliul. O teologie a nădejdii, trad. Victor Manolache, București, Editura Sophia, 2012, p. 19-61. 
În orice caz, teologic privind lucrurile, ceea ce am putea reține de aici este, așa cum sesizează teologul Georgios Mantzaridis, caracterul profund simbolic al actului incinerăriii ${ }^{9}$. Spre deosebire de înhumare sau depunerea trupului în mormânt, arderea şi transformarea lui în cenuşă ne duce nemijlocit cu gândul la ideea de nimicire a acestuia, de aneantizare a lui. Privită astfel, incinerarea este, cum s-a spus, rezultatul unui mod nihilist de a percepe și trăi viaţa ${ }^{10}$. Chiar dacă în opinia unora această afirmație ar putea părea forțată sau subiectivă, râmâne, totuși, o întrebare deschisă în ce măsură în spatele incinerării ca act stă, ca principiu, convingerea actuală a multor indivizi potrivit căreia este imposibil ori ilogic ca acest trup muritor să mai învie vreodată ${ }^{11}$.

${ }^{9}$ Cf. Georgios Mantzaridis, Morala creștină. II. Omul și Dumnezeu; Omul și semenul; Poziționări și perspective existențiale și bioetice, trad. Cornel Constantin Coman, București, Editura Bizantină, 2006, p. 521. Teologul grec afirmă că ,arderea (incinerarea) morților - ca de altfel și îngroparea lor - nu are doar un caracter practic, ci și profund simbolic. Respectiv, faptul de-a prefera arderea morților - sau, dimpotrivă, îngroparea lor - nu se epuizează la nivelul logicii, el ține de ființa profundă a existenței omului; ține de raportarea lui la cel mai acut fenomen al propriei existențe, moartea. Iar sensul pe care omul îl atribuie morții își pune pecetea pe opțiunea lui pentru una din aceste două variante".

${ }^{10}$ A se vedea Răzvan BRUDIU, Incinerarea. Provocare misionară sau contramărturie creștină?, coll. Studia Theologia, Editura Reîntregirea, Alba-Iulia, 2017, p. 222. Părintele Răzvan Brudiu îl citează pe mitropolitul ortodox grec Nikolaos KHADZHINKOLAI care susține următoarele în privința cauzelor profunde ale răspândirii practicii incinerării în zilele noastre: „Societatea, prin arderea morților își contrasemnează nihilismul. O societate care nu suportă omul nici în boala lui, nici în slăbiciune, nici în moarte, o societate care își arde morții, o societate care distruge și amintirea vieții și pomenirea membrilor ei - rămășite trupești -, o societate care face ca începutul omului să fie artificial și opțional, iar sfârșitul lui irevocabil și definitiv, o societate care refuză suflul veșniciei și se ghetoizează în atmosfera sufocantă a efemerului, ce relație poate avea această societate cu viața? Până și ateii păstrau amintirea «dumnezeilor» lor prin îmbălsămări ale trupurilor acestora (cazul lui Lenin) sau, acolo unde acest lucru nu era posibil, prin făurirea unor statui și a altor asemuiri cu persoana. Se pare că rezultatul umanismului fără de Dumnezeu, a culturii fără valori şi a nihilismului fără scop - rezultatul confuziei atee este dispariția omului, arderea până și a ultimelor lui rămășite. Arderea morților conduce la arderea demnității umane"- https://www.pemp tousia.ro/2013/03/incinerarea-mortilor/ (accesat la data de 13.11.2021).

${ }^{11}$ Probabil nu întâmplător o rată mare a incinerărilor se întâlnește în acele state europene în care mare parte dintre locuitori se declară laici sau atei. 
Pe de altă parte, tot așa cum sociologii evidențiază, existența unei mentalități și a unui orizont de gândire seculare nu constituie singura explicație posibilă pentru amploarea practicii incinerării astăzi. Pe lângă argumentele ce țin de sfera religiei și a ritualului creștin ${ }^{12}$, Cynthia Mauro semnalează câteva motive sau argumente de ordin practic-utilitar avansate de persoanele care pledează sau au pledat pentru incinerare ${ }^{13}$. Un prim argument pe care autoarea îl amintește este cel economic. Astfel, dat fiind faptul că incinerarea este mult mai răspândită la oraș decât la sat, se pare că o pondere mare în ceea ce privește luarea deciziei în favoarea incinerării este reprezentată de costurile mai reduse ale incinerării în comparație cu cele ale înhumării. Fără a intra într-o analiză comparată privind costurile incinerării versus înhumării în diferite țări ale Europei, amintim doar faptul că pentru unii eticieni creștini argumentul economic este, în general, discutabil și nu reflectă întotdeauna realitatea ${ }^{14}$. Astfel, s-ar părea că în privința incinerării în joc sunt cauze mult mai profunde decât cele strict de natură economică.

În continuare, un alt argument invocat pentru incinerare este de natură igienică, ecologică ${ }^{15}$. Acest argument a stat, de fapt, la baza înființări primelor crematorii în Europa, în secolul al XIX-lea, când s-a considerat că, prin descompunere, trupurile defuncților depuse în mormânt contribuie la răspândirea epidemiilor, prin aceea că microbii care apar în urma putrezirii trupurilor ar infesta, cu concursul unor fenomene ale naturii (ploaie, vânt) și afecta viețile oamenilor care trăiesc în apropierea cimitirelor. Prin urmare, s-a spus că îngroparea trupurilor în morminte ar fi un lucru cu totul ne-

12 Este vorba, pe de o parte, de toleranța Bisericii Romano-Catolice de după Conciliul II Vatican față de practica incinerării pe care o acceptă, încurajând, totuși, înhumarea, apoi, pe de altă parte, de influența tot mai slabă pe care o are acceași Biserică în ceea ce privește luarea deciziilor de către oameni în favoarea înhumării trupului după moarte.

${ }^{13}$ Cynthia Mauro, „Choisir la crémation aujourd'hui...”, în Études sur la Mort, 132, 2/2007, p. 10-12.

14 Vezi John Breck, Darul sacru al vieții. Tratat de bioetică, trad. Irineu Pop Bistrițeanul, coll. Bioethica, Cluj-Napoca, Editura Patmos, ${ }^{32007, ~ p . ~} 337$.

${ }^{15}$ Cynthia Mauro, „Choisir la crémation...”, p. 11. 
igienic și de aceea incinerarea este cea mai bună alternativă pentru evitarea îmbolnăvirii oamenilor ${ }^{16}$.

Același argument este însă reluat azi de cei care, sub o formă sau alta, aderă la spiritualităţile de tip New-Age și pentru care a te decide pentru incinerare înseamnă a opta pentru prezervarea mediului înconjurător ${ }^{17}$. La o judecată mai riguroasă și acest argument începe să se clatine. Celor care susțin că sicriile nu sunt biodegradabile şi că astfel trupurile intrate în putrefacție ar transmite boli, părintele John Breck le amintește că astăzi se pot lua măsuri necesare astfel încât să se prevină răspândirea unor boli prin intermediul unui trup mort ${ }^{18}$.

Cynthia Mauro consemnează şi argumentul ergonomic susţinut de partizanii incinerării. Conform acestui argument, procesul masiv de extindere prin care trec marile orașe și urbanizarea implicită a zonelor din jurul orașelor ridică problema etică a modului în care trebuie folosit spațiul urban în favoarea celor vii $^{19}$. De aceea, tocmai pentru a se evita suprapopularea cimitirelor urbane și a se valorifica la maximum spațiile urbane se susține că este de preferat incinerarea. Legat de acest ultim fapt, Claude Bersay amintește, de pildă, că în Anglia practica incinerării ar permite anual construirea de stadioane de fotbal în locurile pe care ar putea să le ocupe cimitirile. O dilemă, totuși, se ivește: „Stadioane sau cimitire?”, întreabă retoric autorul citat ${ }^{20}$, însă nu ne este oferit și un răspuns, lăsându-ne parcă pe noi să răspundem acestei interogații etice provocatoare.

16 Vezi o prezentare a acestui argument la Răzvan BRUDIU, Incinerarea ..., p. 224226. Informații prețioase găsim și la Claude BERSAY, „La crémation”, în Études sur la Mort, 125 1/2004, p. 92. O critică teologică a argumentului în cauză aflăm la Nicolae Necula, Atitudinea Bisericii Ortodoxe față de incinerare, București, Basilica, 2013, p. 34-39.

17 Pentru ecologiști, practica incinerării ar fi și un refuz al vizibilității sociale a morții și de integrare a defunctului în entitatea universală. A se vedea legat de această idee comentariul lui Calinic BotoșAnEANUl, Tanatologie și nemurire, Iași, Editura Cantes, 1999, p. 109.

18 John BRECK, Darul sacru al vieții..., p. 337.

${ }^{19}$ Cynthia MAuro, „Choisir la crémation...”, p. 11.

${ }^{20}$ Claude BERSAY, „La crémation”,..., p. 92. 
Pentru justificarea incinerării se invocă și rațiuni de ordin socio-demografic ${ }^{21}$. Dorința de un trai mai bun, ce stă în mod evident la baza nomadismului social actual, conduce de multe ori la o împrăștiere a familiilor, la o separare între adulții și vârstnicii aceleiași familii, ceea ce face ca cei din urmă să aleagă să fie incinerați pentru a-i dispensa pe copiii și familiile lor aflați departe de costurile și de toate sarcinile morale și financiare care revin, de obicei, membrilor familiei atunci când are loc înhumarea. De aceea, conștienți de iminentul lor sfârșit pământesc, se evidențiază că aceste persoane preferă să-și gestioneze singure funeraliile.

Referindu-se la această realitate, părintele Răzvan Brudiu întreabă dacă ,în final, a-i cruța pe cei apropiați de respectiva datorie încredinţată familiei nu este oare un semn al unei anumite neliniști?’”. R. Brudiu ne oferă și o explicaţie a acestei frecvente situații, susținând că ,dorința de a nu deranja pe cei vii înseamnă că această comunitate nu este pregătită să-i însoțească pe cei morți. De aceea, potențialii decedați resimt nevoia de a şterge responsabilitatea tradiţională în gestionarea funeraliilor pe care ar trebui să o îndeplinească familia”. Acest fapt, explică în continuare teologul român amintit, „este o consecință a disparițiilor reperelor sociale, asemenea ritualurilor ce încadrau odinioară viața comunității celor vii, de la naștere până la moarte" 22 .

Pe de altă parte, pentru înțelegerea răspândirii practicii arderii trupurilor moarte astăzi, nu trebuie pierdută din vedere și viziunea postmodernă care declară individul actorul sau artizanul propriei sale vieți ${ }^{23}$. Dacă în zilele noastre individul reclamă mai mult ca niciodată că frâiele vieții sale sunt în mâinile lui, dacă pretinde că are un control suprem asupra destinului său, aceasta îl face să creadă că acest control se exercită și asupra morții sale, și chiar și

${ }^{21} C f$. Cynthia Mauro, „Choisir la crémation...”, p. 11.

${ }^{22}$ Răzvan BRUdIU, Incinerarea..., p. 217.

${ }^{23}$ Vezi o dezvoltare a acestei idei la sociologul David LE BRETON, Antropologia corpului și modernitatea, coll. Cartier istoric, trad. Liliana Rusu, Chișinău, Editura Cartier, 2009, p. 292-296. 
asupra a ceea ce urmează imediat după moartea $\mathrm{sa}^{24}$. Din această perspectivă, pentru omul contemporan incinerarea ,generează potrivit Cynthiei Mauro - un sentiment de libertate și îmbracă o formă de reapropiere a propriei sale morți și a propriei sale deveniri dincolo de moarte" 25 . În plus, față de această evidență, unii analiști evidențiază că industria incineraționistă pare a fi conștientă de dorința omului recent de individualizare și de diversificare, așa încât îi oferă acestuia servicii funerare personalizate, organizate în conformitate cu preferințele și respectând instrucțiunile și scenariul pretins de client ${ }^{26}$.

Între motivațiile în favoarea practicii incinerării se numără, potrivit specialiştilor, și convingerile personale ale indivizilor izvorâte din frica psihologică și repulsia pe care o resimt la gândul că trupul lor neînsuflețit va intra în procesul de descompunere ${ }^{27}$. Așa se face că pentru mulți incinerarea apare astăzi - tot psihologic privind lucrurile - ca o soluție igienică de natură tehnică, capabilă să păcălească realitatea dură a degradării trupului mort ${ }^{28}$, și ar traduce - în plan simbolic - nevoia unei purificări a acestuia ${ }^{29} . \mathrm{Cu}$ toate acestea, după cum subliniază psihiatrul Michel Hanus, în

${ }^{24}$ Obsesia omului contemporan de a deține controlul asupra tuturor aspectelor vieții sale a făcut subiectul mai multor investigații sociologice și antropologice. Mulți sociologi explică acest fapt raportându-l la disoluția marilor narațiuni politicoreligioase care l-au determinat pe individul postmodern să ajungă la concluzia că în timpurile recente destinul său atârnă doar de sine și de nimeni altcineva. În lipsa transcendenței și a rețelelor de sens pe care i le-au furnizat instituțiile moderne, omul modernităţii târzii, aflat sub povara unei libertăţi nelimitate, se vede nevoit să-și dicteze cursul propriei vieți și chiar a posterității.

${ }^{25}$ Cynthia MAUro, „Choisir la crémation...”, p. 12.

${ }^{26} C f$. Ana Ludovico, „Advertising: The rethoric of crematoria”, în Douglas J. DAVIES, Lewis H. MATES (eds.), Encyclopedia of Cremation..., p. 3-4.

${ }^{27}$ Michel HanUs, „La mort aujourd'hui”, ,.., p. 48.

28 François Michaud NÉRARD, La révolution de la mort, préface de Didier Sicard, postface de Bertrand Delanoë, coll. Éspace éthique, Éditions Vuibert, 2007, p. 172.

${ }^{29}$ Unii sociologi consideră că, din punct de vedere simbolic, incinerarea se prezintă ca o acțiune de sublimare a trupului și argumentează această idee referindu-se la gânditori, precum Gaston Bachelard, care au susținut că intensitatea dispariției prin foc (ardere) ar fi dovada ultimă a existenței - $C f$. Marc MAYER, „Cremation et religion...", p. 112 . 
mentalul comun incinerarea este asociată în zilele noastre unei dorințe puternice de suprimare, cât mai repede posibil, a trupului, ca o dovadă de ură sau răzbunare îndreptate împotriva acestuia ${ }^{30}$. Observația psihiatrului francez confirmă, în fapt, o altă observaţie, și mai veche, a unui alt compatriot de-al său, istoricul Philippe Arriès, care, afirma, în urmă cu câteva decenii, că în clipa în care „fuga de moarte a devenit o tentaţie pentru Apus, incinerarea a fost privită ca un mijloc radical de a face să dispară și să se uite orice rămășită a trupului mort" 31 .

Într-o anumită măsură, astfel de observații sociologice devin şi mai evidente dacă adăugăm și faptul că în societatea contemporană, hedonistă, relativistă, postmodernă sau cum mai vrem să o numim, imaginea și forma unui trup atrăgător, mereu tânăr, fără riduri sau sbârcituri ale pielii etc., sunt cultivate în exces și propuse în mod unilateral ca idealuri corporale ${ }^{32}$, cu precădere în mass-media. Și din acest motiv trupul îmbătrânit, bolnav sau la limită, cel neînsuflețit sunt văzute constant într-o notă negativă, depreciativă, lipsite de orice valoare sau respect moral. În acest punct, al viziunii despre trup, s-ar părea că societatea contemporană nu este departe o concepție dualistă, denigratoare a trupului, pe care o redescoperă sau o reafirmă inevitabil atunci când, în mod paradoxal, pune accentul tocmai pe glorificarea trupului tânăr, sănătos cu orice preț. Căci afirmând sau exaltând imaginea sau forma ideală a trupului, credem că societatea contemporană ajunge în fapt să stârnească în oameni și să alimenteze sentimente de ură sau de dispreț față de trupul care nu întrunește calitățile ideale. De aceea, revenind la ideea de la care am pornit reflecțiile noastre de mai sus, incinerarea, ca act prin care se pune în practică dorința insului de suprimare a trupului, reflectă foarte bine contextul cultural actual vizavi de modul paradoxal în care este reprezentat astăzi trupul la nivelul gândirii comune.

${ }^{30}$ Michel Hanus, „La mort aujourd'hui”,,..., p. 48.

${ }^{31}$ Philippe ARIÈs, Essais sur l'histoire de la mort en Occident du Moyen Age à nos jours, Paris, 1975, p. 64.

${ }^{32}$ Răzvan BRUDIU, Incinerarea..., p. 220. 


\section{Atitudinile Bisericilor creștine față de problema incinerării}

Încurajată și propusă de iluminismul ateu și materialist, practica incinerării a atras în Europa numaidecât atenția Bisericii Romano-Catolice care a văzut în acceptarea acesteia în societate o subminare a învățăturii ei despre credința în învierea trupului uman la Parusie. De aceea, a fost oarecum firească reacția Bisericii Romano-Catolice de a respinge cremațiunea și de a-și exprima poziția nefavorabilă față de aceasta prin câteva documente oficiale $^{33}$. Cu toate acestea, așa cum evidențiază R. Brudiu, odată cu Conciliul II Vatican se înregistrează mutații vizibile de optică în această chestiune stringentă a incinerării. Condamnată la început, practica incinerării este acceptată după anul 1963 de către Biserica Catolică, fără a o substitui însă înhumării, cu condiția ca opțiunea pentru incinerare să nu aibă la bază negarea învățăturii creștine despre învierea trupurilor ${ }^{34}$.

În comparație cu Biserica Romano-Catolică, Biserica Protestantă (calvină și luterană) a dovedit față de problema incinerării o poziție mult mai deschisă, acceptându-o cu puțin înainte de începutul secolului al XX-lea, în $1898^{35}$. În opinia unui teolog protestant, practica cremaționistă nu este contrară doctrinei biblice și nici înhumării, deoarece atât incinerarea, cât și înhumarea

${ }^{33}$ A se vedea, în acest sens, decretele: Quoad cadaverum cremationes (din 19 mai 1886); Quoad corporum cremationem (din 15 decembrie 1986) și De crematione cadaverum (din 19 iunie 1926). Mai multe detalii privind poziţia Bisericii Romano-Catolice asupra cremațiunii ne oferă Răzvan BRUDIU, Incinerarea..., p. 247-252.

${ }^{34}$ Răzvan Brudiu, Incinerarea..., p. 255. A se vedea și studiul lui M. RIQUERT, „L'Église catholique romaine sur la crémation”, în Positions luthériennes, 27/1979, p. 119-123.

35 Am găsit această informație la Pierre FAURE, „Le choix de la crémation”, în Études, Tome 406, 2/2007, p. 185-196, aici p. 186. Pentru lărgirea orizontului privind poziția Bisericii Protestante față de incinerare a se consulta și A. DumAs, „Les Églises protestantes et la crémation”, în Positions luthériennes, 27/1979, p. 124-127. 
au drept rezultat transformarea trupului neînsuflețit în praf, cenușă, numai că în cazul celei de-a doua durează ceva mai mult. Prin urmare, din această perspectivă, pentru teologia protestantă arderea unui cadavru nu este un impediment în calea învierii trupului, întrucât această înviere este, de fapt, o nouă creație ${ }^{36}$.

În ceea ce o privește, Biserica Ortodoxă este foarte fermă în decizia ei de a nu accepta practica arderii trupurilor defuncților ${ }^{37}$. $\mathrm{Cu}$ toate că documentele oficiale care interzic incinerarea sunt foarte puține, așa cum precizează Jean-Claude Larchet, poziția Bisericii Ortodoxe față de problematica incinerării este exprimată prin vocile a mai multor ierarhi ai bisericilor locale ${ }^{38}$, care se pronunță categoric împotriva arderii trupurilor celor răposați. $\mathrm{O}$ excepție o constituie Biserica Ortodoxă din Japonia care acceptă incinerarea, deoarece există o lege a statului care prevede acest lucru.

36 Vezi Jean-Paul GUETNY, „Religions et crémation”, în Études sur la mort, 140, 2/2011, p. 81-90, aici p. 86.

37 Stanley S. HARAKAS, Contemporary moral issues. Facing the Orthodox Christian, Minneanopolis, 1982, p. 181. Moralistul ortodox notează în alt loc: „Odată cu ivirea Iluminismului, în veacul al XVIII-lea, s-a produs un transfer de la credința în Dumnezeu la încrederea și spiritul omului. Într-un climat de anticlericalism şi de neîncredere, incinerarea a devenit un mijloc concret de a înfrunta Biserica și de a nega totodată învierea cu trupul. Incinerarea a devenit astfel expresia supremă a credinței în completa anihilare a persoanei umane odată cu moartea fizică. În aceste circumstanțe, Biserica, pe lângă grija pastorală de a menține adevărata credință a credincioșilor ei, a socotit că este înțelept să ia poziție față de această practică. Şi chiar dacă incinerarea nu mai este larg practicată ca o lepădare de Dumnezeu și o negare a învierii, Biserica continuă să păzească adevărurile fundamentale neschimbate ale credinței noastre de astfel de idei străine de învățătura ei”, p. 182.

38 Jean-Claude LARCHET, Sfârșit creștinesc vieții noastre, fără durere, neînfruntat, în pace..., trad. Marinela Bojin, București, Editura Basilica a Patriarhiei Române, 2012, p. 304. Patrologul francez amintește legat de interzicerea incinerării de anumite documente oficiale emise de câtiva ierarhi după 1900. De pildă, într-o scrisoare datată 24 aprilie/6 mai 1928 și adresată patriarhului Varnava al Serbiei, mitropolitul Antonie Krapoviţki al Bisericii Ortodoxe Ruse din Diaspora scris că acceptarea practicii incinerării înseamnă o încălcare a datinii cucernice străbune de a îngropa morții. A se vedea, pentru mai multe detalii, exemplele pe care le oferă teologul francez citat. 
În Diaspora, Mitropolia Ortodoxă a Germaniei, Europei Centrale și de Nord arată că a luat act de înmulțirea cazurilor de incinerare în zonele unde își desfășoară activitatea. Într-un scurt comunicat datat septembrie 2005 și publicat pe pagina oficială a Mitropoliei Germaniei se arată că, deși, incinerarea este o opțiune pentru unii datorită rațiunilor ei practice (de pildă, costuri reduse etc.), totuși, se subliniază că această practică nu este una creștină și de aceea Biserica nu o încurajează. Dacă, totuşi, există familii care insistă pentru incinerarea trupurilor, comunicatul oficial prevede oficierea slujbei înmormântării înaintea incinerării. În situația în care cineva, din neștiință sau din alte motive îi va aduce la cunoștință preotului despre decesul unei persoane abia după ce trupul acesteia a fost incinerat, preotul nu va mai săvârși slujba înmormântării, ci pe cea a Parastasului cu citirea Apostolului şi a Evangheliei ${ }^{39}$.

Există, însă, și teologi ortodocși care adoptă o poziție mai deschisă față de problema incinerării. În acest sens, profesorul Anastasios Kallis consideră că pentru Biserica Ortodoxă nu există vreun motiv pentru a dogmatiza înhumarea, iar în cazul unei incinerări să refuze oficierea slujbei de înmormântare, cu toate că ritul înmormântării exclude practica incinerării. Anastasios Kallis nu vede în incinerare o problemă de ordin dogmatic, ci una de natură pastorală, pe care Biserica Ortodoxă este datoare să o gestioneze adecvat insistând pe sensibilizarea credincioșilor față de cei răposați. În plus, Anastasios Kallis arată că dacă la începutul secolului trecut incinerarea punea probleme de credință, astăzi în cazul practicării acesteia sunt avute în vedere chestiuni legate de igienă ${ }^{40}$.

39 Vezi comunicatul oficial la adresa de internet http://www.mitropoliaro.de/index.php/ro/publicatii/comunicate/22-despre-incinerare (accesat la data de 13.11.2021). A se vedea şi Adrian ZAHARIA, „Incinerarea din punct de vedere ortodox", în Teologie și Viață, 1-4/2010, p. 128.

${ }^{40}$ Vezi pentru mai multe detalii Anastasios KALLIS, Das hätte ich gerne gewußt. 100 Fragen an einen orthodoxen Theologen, Theofano Verlag, Münster, 2003, p. 289. Vezi și Răzvan BRUDIU, „Cu moartea pe moarte călcând”. Dimensiunea liturgic-misiologică a slujbei înmormântării, Stockholm, Editura Felicitas, Stockholm, 2020, p. 218-220. 


\section{Scurte considerații vizavi de fenomenul incinerării din perspectivă ortodoxă}

Pentru Biserica Ortodoxă, problema morții și a tratamentului aplicat trupului imediat după neînsuflețirea lui sunt și trebuie privite din perspectiva deschisă, pe de o parte, de antropologia biblică și patristică și, pe de altă parte, de conținutul hristologic și soteriologic al antropologiei creștine în ansamblul ei. Or, privind lucrurile în acest sens, incinerarea nu poate să fie acceptată de către Biserică. Incinerarea face notă discordantă atât cu tot ceea ce ne descoperă istoria şi teologia biblică a Vechiului și Noului Testament, cât și cu ceea ce ne pune la dispoziție Tradiția creștină privitor la soarta trupului după moartea acestuia.

Din perspectiva istoriei și antropologiei biblice, așa cum subliniază patrologul Jean-Claude Larchet, obiceiul înmormântării trupului sau a depunerii lui în pământ nu reprezintă altceva decât punerea în aplicare, concretizarea cuvântului lui Dumnezeu, rostit imediat după căderea omului în păcat ${ }^{41}$. „Pământ ești și în pământ te vei întoarce" $(F c 3,9)$. Din paginile Sfintei Scripturi observăm că înmormântarea a fost practicată de evrei și era văzută ca o datorie importantă ce trebuie respectată cu strictețe ${ }^{42}$. Vechiul Testament abundă de exemple care arată că trupurile morților erau înmormântate fie în morminte ale familiei, fie în morminte străine. În Facerea 23, v. 3; 8, de pildă, ni se spune că Avraam a cumpărat peștera de la Macpela pentru a îngropa trupul soției sale Sarra. Avraam a cerut un loc de îngropare și i s-a spus să-și aleagă cel mai bun loc dintre locurile de îngropare care existau la Hebron: „Eu sunt străin și pribeag; dați-mi, dar, în stăpânire un loc de mormânt, ca să îngrop pe moarta mea" $(F c$ 23, 6). În acest mormânt vor fi îngropați și alți membrii ai familiei lui Avraam, precum Isaac și Rebeca (Fc 49, 30-31).

${ }^{41}$ Jean-Claude LARCHET, Sfârșit creștinesc vieții noastre..., p. 323.

42 Vezi Alexandru MıHĂILĂ, ,Concepția despre moarte și grija față de cei adormiți în Vechiul Testament (I)", în Ortodoxia, 3/2012, p. 123-142, aici p. 129. 
În ceea ce îl privește pe Iosif, chiar dacă trupul lui a fost îmbălsămat după ce a murit și a fost pus într-un sicriu, dorința lui a fost aceea ca rudele sale să ducă oasele lui afară din Egipt, și probabil tot acolo unde au fost înmormântaţi strămoșii lui $(F c 50,25)$. Despre obiceiul înmormântării la evrei avem dovezi și în alte cărți ale Vechiului Testament. Cartea 4 Regi 2, 32 menționează faptul că regele David aduce trupul lui Asael pentru a-1 depune în mormântul familiei din Betleem, iar în 2 Regi 3, 31-32 se consemnează că trupul lui Abner este pus în alt mormânt decât cel al familiei lui.

În ceea ce privește pregătirea trupului pentru înmormântare aceasta era precedată de unele datorii ce reveneau membrilor familiei, precum aceea de a închide ochii defunctului $(F c 46,4)$ și a-i da acestuia ultima sărutare în semn de despărțire $\left(F_{c} 50,1\right)^{43}$.

Este drept că practica incinerării este consemnată în paginile Scripturii Vechiului Testament, însă aceasta a fost împrumutată de către evrei de la popoarele păgâne și reprezenta în fapt o pedeapsă pentru unele păcate de necinste precum incestul sau desfrânarea, ori pentru aducerea unor jertfe necorespunzătoare voinței lui Dumnezeu $^{44}$. „Dacă își va lua cineva femeie și va desfrâna cu mama ei, nelegiuire face; pe foc să se ardă și el și ea, ca să nu fie nelegiuri între voi”, citim în cartea Leviticul 20, v. $14^{45}$.

Înmormântarea era în vigoare și în timpul Noului Testament. Evangheliile consemnează la rândul lor faptul că trupul Sfântului Ioan Botezătorul a fost îngropat după ce a fost decapitat la porunca

43 Cf. Dumitru Abrudan, Emilian Cornițescu, Arheologie Biblicăa ediția a II-a, București, Editura Institutului Biblic și de Misiune al Bisericii Ortodoxe Române, 2002, p. 128-129. A se vedea și Alexandru MiHĂILĂ, „Concepția despre moarte și grija față de cei adormiți în Vechiul Testament (II)", în Ortodoxia, 1/2013, p. 6779. Biblistul român notează şi alte practici funerare din iudaism, extrase din Mișna, Talmud precum și alte documente iudaice rabinice.

44 Jean-Claude LARCHET, Sfârșit creștinesc vieții noastre..., p. 313.

45 Este vorba de arderea celor care se făceau vinovați de încălcarea legii lui Dumnezeu. Din textul biblic nu reiese foarte clar dacă acești vinovați erau arși de vii sau ucişi și apoi dați focului, incinerați. Cert este faptul că această ardere avea nu doar un caracter punitiv, ci și expiator. Vezi nota explicativă la Levitic 20, 14 în Septuaginta 1, coord. Cristian BadilițA, Francesca Baltaceanu, Monica Broșteanu, Dan Slușanschi, în colaborare cu Ioan-Florin Florescu, Iași, Colegiul Noua Europă / Editura Polirom, 2004, p. 388. 
lui Irod. „Și auzind, ucenicii lui au venit, au luat trupul lui Ioan și 1-au pus în mormânt" $(M c 6,29)$. Însă cel mai important argument pentru obiceiul îngropării trupurilor celor răposați este faptul că însuși trupul lui Iisus Hristos a fost așezat într-un mormânt nou după ce acesta și-a dat duhul (Mt 27, 60; $M c$ 15, 46). ,Și coborându-L, L-au înfășurat în giulgiu de in și L-a pus într-un mormânt săpat în piatră, în care nimeni, niciodată, nu mai fusese pus" ( $L c 23,53)$. Potrivit lui JeanClaude Larchet punerea în mormânt a Mântuitorului Iisus Hristos capătă valoare arhetipală pentru creștini, întrucât așa cum Hristos a fost înmormântat se cuvine fiecărui creștin să fie înmormântat în aşteptarea învierii trupului său la Parusia Domnului ${ }^{46}$.

Tradiţia liturgică a Bisericii va prelua și va dezvolta toate aceste date scripturistice în ritul și slujba înmormântării. Pregătirea trupului celui decedat, prohodirea lui la Biserică, imnografia slujbei de înmormântare, însoțirea trupului celui adormit la mormânt, așezarea trupului în mormânt cu fața spre Răsărit, toate aceste acte profund simbolice acoperă un realism antropologic și duhovnicesc evident, de necontestat: chiar și atunci când este lipsit de viaţă și neînsuflețit, trupul este, cum bine surprinde părintele Stanley Harakas, bun şi demn de respect din punct de vedere creștin ${ }^{47}$, bucurându-se de atenția cuvenită după moarte ${ }^{48}$. Acest fapt se fundamentează pe realitatea că materia în creștinism și, mai cu seamă, materia din care este alcătuit trupul omenesc, reflectă bunătatea creației lui Dumnezeu.

Mai mult, chiar și după despărțirea sufletului de trup, acesta din urmă este și rămâne parte integrală a omului, întrucât din punctul

46 Jean-Claude LARCHET, Sfârșit creștinesc vieții noastre..., p. 331.

47 Vezi, în acest sens, Stanley S. HaraKas, „Pastoral Guidelines: Church Positions Regarding the Sanctify of Human Life", la adresa de internet: https://www.goarch.org/en/-/pastoral-guidelines-church-positions-regarding-thesanctity-of-human-life, subcapitolul „Cremation” (accesat la data de 13.11.2021).

48 „Dacă Biserica Ortodoxă recomandă înhumarea o face în mod deosebit dintr-un respect și o prețuire aleasă față de ființa umană, un respect pe care i-1 acordă nu doar în timpul vieții, ci și după moarte, nu numai atunci când este sănătoasă, ci şi în stare de suferință, ba chiar și trupului neînsuflețit” - Ioan C. TEȘU, „Înhumarea versus incinerare", https://doxologia.ro/puncte-de-vedere/inhumare -versus-incinerare (accesat la data de 13.11.2021). 
de vedere al antropologiei biblice omul este compus din suflet și trup. Prin moarte trupul nu se nimicește, ci doar se descompune în elementele din care este alcătuit ${ }^{49}$. De aceea, cu privire la chestiunea dacă relația dintre suflet și trup se păstrează și după moartea omului, mitropolitul Hierotheos Vlahos remarcă ideea că, deși sufletul şi trupul sunt despărțite prin survenirea morții biologice, ipostasul sau unitatea persoanei nu este desființată sau distrusă ca urmare a acestui fapt $^{50}$. În fapt, suntem de părere că în persoana umană, între sufletul și trupul acesteia există o legătură strânsă, apofatică, imposibil de explicat până la capăt prin rațiunea omenească, de aceea trebuie acceptată ca taină a persoanei, o legătură însă ce nu poate fi desființată nici chiar de moartea biologică.

Pe aceeași linie de argumentare se situează și teologul ortodox Jean-Claude Larchet, atunci când menționează că, deși prin moartea fizică se întrerupe relația firească existentă între suflet și trup, ca două părți constitutive ale persoanei, totuși legătura dintre cele două componente din care este alcătuită ființa umană se păstrează într-o anumită formă, iar legătura dintre ele rămâne neștirbită. În plus, arată teologul francez, legătura de nedesfăcut dintre suflet și trup se continuă și dincolo de moarte, se păstrează chiar și după ce are loc fenomenul descompunerii trupului neînsuflețit. Jean-Claude Larchet aduce în acest sens ca argument patristic o explicaţie a Sfântului Maxim Mărturisitorul cu privire la legătura strânsă care se păstrează între suflet și trup chiar și după încetarea din viața a unei persoane ${ }^{51}$. Sfântul Maxim Mărturisitorul scrie că: „după moartea trupului,

49 „Este drept că trupul se destramă pe încetul, dar nu se nimicește, căci nimicirea e tocmai trecerea în neexistență, câtă vreme destrămarea e numai o împrăștiere, respectiv o întoarcere a trupului la stihiile pământene din care a fost luat. Iar ceea ce se află în această stare nu se pierde, cu toate că aceasta trece dincolo de înțelegerea noastră simțuală” - $c f$. SFÂNTUL GRIGORIE DE NYSSA, Marele cuvânt catehetic, 8, în Sfântul GrIGORIE DE NYSSA, Scrieri. Partea a doua. Scrieri exegetice, Dogmatico-poetice și Morale, PSB 30, trad. Teodor Bodogae, București, Editura Institutului Biblic și de Misiune al Bisericii Ortodoxe Române, 1998, p. 302.

${ }^{50}$ Mitropolitul Ierotheos Vlahos, Bioetică și bioteologie, trad. Teofan Munteanu, București, Editura Christiana, 2013, p. 221.

${ }^{51}$ Jean-Claude LARCHET, Sfârșit creștinesc vieții noastre..., p. 293. 
sufletul nu se mai numește simplu suflet, ci suflet al omului și suflet al unui oarecare om. Căci și după trup (după moartea trupului) are ca specie a lui întregul uman, drept caracteristică ce îi revine ca unei părți a acestuia în baza relației. La fel și trupul e muritor după fire, dar nu este dezlegat de întregul uman din pricina nașterii Căci nu se numește trupul simplu trup, după despărțirea de suflet, ci trup al omului și trup al unui oarecare om, chiar de se corupe și se dizolvă în elementele din care este. Căci are și așa, ca parte a speciei lui, întregul uman drept caracteristică ce îi revine ca unei părți a acestui întreg în baza relației. În amândouă, adică și în suflet și în trup, relaţia cugetându-se ca ceva ce nu poate fi smuls, întrucât sunt părți ale întregii specii umane, înfățișează și aducerea lor la existență și dovedește și deosebirea între ele după ființă. Deci, nu e cu putință peste tot a afla sau numi vreun trup sau suflet în afara relației dintre ele. Căci deodată cu partea se arată și aceea că este parte a cuiva. Încât dacă preexistă o parte alteia, e implicat în ea și întregul a cărui parte este. Căci relația ei este de neînlăturat"52.

Părintele Théodore Papanicolaou remarcă faptul că unii Părinţi ai Bisericii au văzut o binefacere nu numai în moarte ca fenomen biologic, ci și în descompunerea trupului ${ }^{53}$. Aceștia urmează astfel interpretarea duhovnicească paulină din prima epistolă către Corinteni, capitolul 15, versetele 42-44. Părintele Th. Papanicolaou îl citează în acest sens, printre alții, pe Sfântul Teofil al Antiohiei care se folosește de comparația cu vasul defect, retopit și refăcut nou și întreg, pentru a sublinia rolul binefăcător al morții. Conform acestuia din urmă, trupul omului trebuie să treacă prin moarte și, deci, prin descompunere pentru ca, ulterior, la înviere să fie făcut „fără pată, drept și nemuritor” ${ }^{54}$. Este evidentă în acest caz

52 Sfântul Maxim Marturisitorul, Ambigua, trad. Dumitru Stăniloae, PSB 80, București, Editura Institutului Biblic și de Misiune al Bisericii Ortodoxe Române, 1983, p. 100-101.

53 Théodore PAPANICOLAOU, Viziunea morții în lumina Sfinților Părinți ai Bisericii. Eseu de spiritualitate ortodoxă, coll. Agora 1, trad. Paula Ilaș, Iași, Editura Doxologia, 2016, p. 63.

54 Sfântul TeOfIL AL ANTIOHIEI, Trei cărți către Autolic, II, 26, în Apologeți de limbă greacă, PSB 2, trad. D. Fecioru, București, Editura Institutului Biblic și de Misiune al Bisericii Ortodoxe Române, 1980, p. 314. 
ideea de renaștere a trupului îngropat într-o altă modalitate de existență, idee, de altfel, cu profunde rezonanțe evanghelice (In 12, $24)^{55}$. Pe de altă parte, Sfântul Ioan Hrisostom, citat la rândul său de către teologul francez de mai sus, afirmă clar că prin descompunerea trupului nu dispare ființa trupului, ci ceea ce este muritor în trup, adică păcatul ${ }^{56}$. Prin urmare, evaluând perspectivele Părinților purtători de Dumnezeu asupra semnificației morții în general, părintele Th. Papanicolaou apreciază că aceștia sunt „,convinși că moartea trupului intensifică lucrarea «catalitică» a lui Dumnezeu în beneficiul omului". De aceea, conchide același autor, „moartea, cu toate că poartă însemne fataliste, se transformă într-o mare binefacere prin voința lui Dumnezeu"

În baza acestor considerente de ordin teologic și antropologic expuse mai sus, putem considera împreună cu părintele Stanley Harakas că „Biserica Ortodoxă consideră incinerarea o desacralizare deliberată și o distrugere a ceea ce Dumnezeu a făcut și a rânduit pentru om" "58.

În privința gravității ei, practica incinerării a fost comparată cu cea a sinuciderii. În acest sens, părintele Adrian Zaharia este de părere că, așa cum cel care cu deplină cunoștință își distruge trupul prin diverse mijloace, tot așa cel care optează pentru ca trupul să-i fie ars după moarte, poate fi considerat că acționează ca un sinucigaș, dat fiind faptul că antropologia creștină nu desparte sufletul de trup, ci le gândește mereu împreună. Din această perspectivă, incinerarea este calificată de către autorul citat ca fiind o sinucidere parțială ${ }^{59}$.

Trecând la un alt registru al ideilor, faptul că trupul este păstrat cu grijă în cimitir are o semnificație teologică aparte ${ }^{60}$,

55 Jean-Claude LARCHET, Sfârșit creștinesc vieții noastre..., p. 328.

56 Sfântul IoAn Gura DE Aur, Omilii la Matei, XXXIV, 4, în Scrieri. Partea a treia, PSB 23, trad. D. Fecioru, București, Editura Institutului Biblic și de Misiune al Bisericii Ortodoxe Române, 1994, p. 427.

57 Théodore PAPANICOLAOU, Viziunea morții..., p. 65.

58 Stanley S. HARAKAS, „Pastoral Guidelines: Church Positions Regarding the Sanctify of Human Life".

${ }^{59}$ Adrian ZAHARIA, „Incinererea din punct de vedere ortodox”, ..., p. 129.

${ }^{60}$ Așa cum evidențiază Părintele Patriarh Daniel, cimitirul are în limbajul creștin sensul de „dormitor” sau „loc de odihnă”, acolo unde trupurile celor răposați 
cimitirul fiind locul unde cel adormit odihnește cu trupul în așteptarea învierii lui la Parusia Domnului Iisus Hristos. În acest sens, dacă luăm în calcul că moartea este văzută în creștinism vorbind simbolic, dar înțelegând-o duhovnicește - ca adormire, iar nu ca dispariție în neant a omului, a trupului acestuia, devine limpede cu atât mai mult de ce trupul nu trebuie nimicit, ars sau transformat în pulbere, ci înmormântat. Înmormântarea trupului constituie în această perspectivă o problemă de natură dogmatică, liturgică, misionară, morală și pastorală în același timp, deoarece Biserica mai bine de două milenii a propovăduit că Iisus Hristos ,,sa răstignit (...), a pătimit și $s$-a ingropat și a înviat a treia zi după Scripturi" (art. 4 din Simbolul de credință). Dacă Biserica ar accepta incinerarea ca practică funerară, atunci ar trebui să schimbe mare parte din însuși conținutul imnelor liturgice care cu preponderență se referă la trupul ce este depus în mormânt.

Faptul că sufletul păstrează o legătură cu trupul după moarte este dovedit de realitatea sfintelor moaște sau a rămăşitelor pământești ale sfinților sau chiar ale creștinilor. Mai ales în cazul persoanelor cu viață sfântă, aleasă, îmbunătățită, sfințenia sufletului dobândită de acestea pe parcursul vieții pământești se reflectă și asupra trupului acestora și a rămășitelor lor pământești după moarte. De aceea, harul lui Dumnezeu care lucrează asupra sufletului acestor persoane deosebite duhovnicește, lucrează și prin intermediul trupului și a rămășitelor pământești ale acestor persoane cu viaţă aleasă după trecerea lor la cele veșnice, arătându-le făcătoare de minuni și de vindecări. Așa se face că, potrivit teologului Jean-

odihnesc în așteptarea învierii de obște. În fapt, arată mai departe Patriarhul Bisericii Ortodoxe Române, care este meritul creștinismului de a fi schimbat numele locului unde se depuneau trupurile neînsuflețite din necropolă, adică „locuință a morților”, în cimitir, adică „dormitor”. Rațiunea schimbării numelui locului de îngropare din necropolă în cimitir, stă în aceea că mort cu adevărat este doar considerată doar ființa umană care este despărțită de Dumnezeu. Din acest motiv, în creștinism se întrebuințează denumirea de ,adormit/ă în Domnul" celui/celei decedat/e. Vezi, pentru mai multe detalii, † DANIEL, Patriarhul Bisericii Ortodoxe Române, „Iubirea, mai tare decât moartea. Înțelesul și folosul pomenirii morților", în Știința mântuirii. Vocația mistică şi misionară a teologiei, București, Editura Basilica, 2014, p. 128. 
Claude Larchet, care îl aduce în discuție la rândul lui pe părintele John Breck, importanța acordată sfintelor moaște reprezintă la rândul ei un argument cu greutate împotriva practicării incinerării ${ }^{61}$.

\section{Concluzii}

Incinerarea este o practică funerară care câștigă în Occident tot mai mult teren. Pe parcursul ultimelor două secole, motivaţia justificării ei a variat de la considerarea acesteia un afront adus viziunii creștine despre învierea trupului (în Iluminism) la perceperea ei fie ca o soluție igienică cu privire la soarta trupului după neînsuflețirea lui, fie ca o dovadă a autonomiei individului postmodern care poate să decidă ce să se întâmple cu trupul său după moarte. Oricum, în ambele situații enunțate mai sus și în multe altele asemănătoare, incinerarea constituie pentru Biserică o provocare actuală, și mai ales pentru creștinii care îşi duc viața în comunităţile occidentale, acolo unde incinerarea este prezentată adesea ca o soluție practică, la îndemână, vizavi de soarta imediată trupului după moarte. $\mathrm{Cu}$ excepția cazurilor unde incinerarea este impusă prin lege (ex. cazul Japoniei), Biserica Ortodoxă îndeamnă și propune creștinilor înhumarea trupului după moarte, ca reprezentând practica funerară legitimă, conformă cu învăţătura sa bimilenară despre persoana umană, vocația și destinul acesteia în Împărăția lui Dumnezeu. Cu toate că prin moartea biologică sufletul se desparte pentru o perioadă de trup, între cele două componente ale persoanei rămâne o legătură strânsă, chiar şi după mormânt. Trupul pus în mormânt este și rămâne parte a unei persoane anume, deci nu este complet nimicit. Însăşi așezarea lui în groapa mormântului, cu ample și adânci semnificații simbolice, acoperă, spiritual vorbind, un veritabil realism antropologic: cel așezat în mormânt experiează moartea ca un somn prelung în așteptarea învierii lui la cea de-a Doua Venire a lui Hristos. La Parusia Domnului, identitatea trupului înviat va fi păstrată. Ceea ce însă va fi profund schimbată, va fi forma de existență a acestuia. Va fi un

${ }^{61}$ Jean-Claude LARCHET, Sfârșit creștinesc vieții noastre..., p. 337. 
trup penetrat de energiile Duhului, un trup translucid, diafan, pnevmatizat, covârşit de prezența sufletului din el.

$\cos 80$

\section{Bibliografie}

1. $\dagger$ DANIEL, Patriarhul Bisericii Ortodoxe Române, ,Iubirea, mai tare decât moartea. Înțelesul și folosul pomenirii morților", în Știința mântuirii. Vocația mistică și misionară a teologiei, București, Editura Basilica, 2014, p. 126-130.

2. Septuaginta 1, coord. Cristian BĂDILIȚĂ, Francesca BĂLTĂCEANU, Monica BRoȘTEANU, Dan SLUȘANSCHI, în colaborare cu IoanFlorin Florescu, Iași, Colegiul Noua Europă / Editura Polirom, 2004.

3. Abrudan, Dumitru, Cornițescu, Emilian, Arheologie Biblică, ediția a II-a, București, Editura Institutului Biblic şi de Misiune al Bisericii Ortodoxe Române, 2002.

4. ARIÈs, Philippe, Essais sur l'histoire de la mort en Occident du Moyen Age à nos jours, Paris, 1975.

5. ARIÈS, Philippe, L'homme et la mort, coll. Univers historique, Éditions du Seuil, Paris, 1977.

6. BERCHOUD, Joseph, „La crémation”, în Études sur la Mort, 132, 2/2007, p. 101-109.

7. BERSAY, Claude, „La crémation”, în Études sur la Mort, 125, 1/2004, p. 91-96.

8. BRECK, John, Darul sacru al vieții. Tratat de bioetică, trad. Irineu Pop Bistriţeanul, coll. Bioethica, Cluj-Napoca, Editura Patmos, ${ }^{3} 2007$.

9. BRUDIU, Răzvan „CU moartea pe moarte călcând”. Dimensiunea liturgic-misiologică a slujbei înmormântării, cuvânt înainte de PS Macarie, Stockholm, Editura Felicitas, 2020.

10. BRUDIU, Răzvan, Incinerarea. Provocare misionară sau contramărturie creștină?, coll. Studia Theologia, Alba Iulia, Editura Reîntregirea, 2017.

11. CALINIC BotoșãNEANUl, Tanatologie și nemurire, Iași, Editura Cantes, 1999.

12. DAvieS, Douglas J., MATES, Lewis H. (eds.), Encyclopedia of Cremation, Ashgate, Printed in Great Britain, 2005. 
13. Dumas, A., „Les Églises protestantes et la crémation”, în Positions luthériennes, 27/1979, p. 124-127.

14. DuȚU, Gheorghe, Dicționar latin-român, București, Editura Humanitas, 2003.

15. Faros, Filoteu, Moartea și doliul. O teologie a nădejdii, trad. Victor Manolache, București, Editura Sophia, București, 2012.

16. FAURE, Pierre „Le choix de la crémation”, în Études, tome 406, 2/2007, p. 185-196.

17. GRÉVIN, Gilles, „Apport archéologique et médico-légal de l'étude de la crémation sur brûcher en Inde et au Népal", în Études sur la Mort, 132, 2/2007, p. 23-28.

18. SfÂNTUL GRIGORIE DE NYSSA, Scrieri. Partea a doua. Scrieri exegetice, Dogmatico-poetice și Morale, PSB 30, trad. Teodor Bodogae, București, Editura Institutului Biblic și de Misiune al Bisericii Ortodoxe Române, 1998.

19. GUETNY, Jean-Paul, „Religions et crémation”, în Études sur la mort, 140, 2/2011, p. 81-90.

20. HANUS, Michel, „La mort aujourd'hui', în Études sur la Mort, 125 1/2004, p. 39-49.

21. HARAKAS, Stanley S., Contemporary moral issues. Facing the Orthodox Christian, Minneanopolis, 1982.

22. Mitropolitul IEROTHEOS Vlahos, Bioetică și bioteologie, trad. Teofan Munteanu, București, Editura Christiana, 2013.

23. IlOAIE, Ștefan, „Taina morții ca taină a vieții. Atitudinea creștinului față de moarte", în Tabor, 6/2007, p. 5-9.

24. SFAnTUl IOAN GuRA DE AUR, Omilii la Matei, XXXIV, 4, în Scrieri. Partea a treia, PSB 23, trad. Dumitru Fecioru, București, Editura Institutului Biblic și de Misiune al Bisericii Ortodoxe Române, 1994.

25. Kallis, Anastasios, Das hätte ich gerne gewußt. 100 Fragen an einen orthodoxen Theologen, Theofano Verlag, Münster, 2003.

26. LARCHET, Jean-Claude, Sfârșit creștinesc vieții noastre, fãră durere, neînfruntat, în pace..., trad. Marinela Bojin, București, Editura Basilica a Patriarhiei Române, 2012.

27. LE BRETON, David, Antropologia corpului și modernitatea, coll. Cartier istoric, trad. Liliana Rusu, Chișinău, Editura Cartier, 2009.

28. MANTZARIDIS, Georgios, Morala creștină. II. Omul și Dumnezeu; Omul și semenul; Poziționări și perspective existențiale și bioetice, trad. Cornel Constantin Coman, București, Editura Bizantină, 2006. 
29. MAUro, Cynthia, „Choisir la crémation aujourd'hui...”, în Études sur la Mort, 132 2/2007), p. 9-18.

30. SFÂNTUL MAXIM MĂRTURISITORUL, Ambigua, trad. Dumitru Stăniloae, PSB 80, București, Editura Institutului Biblic și de Misiune al Bisericii Ortodoxe Române, 1983.

31. MAYER, Marc, „Cremation et religion dans notre monde secularisé”, în Études sur la Mort, 132, 2/2007, p. 111-115.

32. MIHĂILĂ, Alexandru, „Concepția despre moarte și grija faţă de cei adormiți în Vechiul Testament (I)", în Ortodoxia, 3/2012, p. 123142.

33. MIHĂILĂ, Alexandru, „Concepția despre moarte și grija față de cei adormiți în Vechiul Testament (II)", în Ortodoxia, 1/2013, p. 6779.

34. NeCUla, Nicolae, Atitudinea Bisericii Ortodoxe față de incinerare, București, Basilica, 2013.

35. NÉRARD, François Michaud, La révolution de la mort, préface de Didier Sicard, postface de Bertrand Delanoë, coll. Éspace éthique, Éditions Vuibert, 2007.

36. PAPANICOLAOU, Théodore, Viziunea morții în lumina Sfinților Părinți ai Bisericii. Eseu de spiritualitate ortodoxă, coll. Agora 1, trad. Paula Ilaș, Iași, Editura Doxologia, 2016.

37. RIQUERT, M., „L'Église catholique romaine sur la crémation”, în Positions luthériennes, 27/1979, p. 119-123.

38. RoHDE, Erwin, Psyché, trad. Mircea Popescu, București, Editura Meridiane, 1985.

39. SfÂNTUL TEOFIL AL ANTIOHIEI, Trei cărți către Autolic, II, 26, în Apologeți de limbă greacă, PSB 2, trad. D. Fecioru, București, Editura Institutului Biblic și de Misiune al Bisericii Ortodoxe Române, 1980.

40. ZAHARIA, Adrian, „Incinererea din punct de vedere ortodox”, în Teologie și Viață 1-4/2010, p. 114-131.

41. http://www.mitropoliaro.de/index.php/ro/publicatii/comunicate/22-despre-incinerare.

42. https://www.cremation.org.uk/international-statistics-2007\# (accesat la data de 13.11.2021).

43. https://www.cremation.org.uk/international-statistics-2017 (accesat la data de 13.11.2021).

44. HARAKAS, Stanley S., „Pastoral Guidelines: Church Positions Regarding the Sanctify of Human Life", la adresa de internet: https://www.goarch.org/en/-/pastoral-guidelines-church-positions- 
regarding-the-sanctity-of-human-life (accesat la data de 13.11.2021).

45. NICOLAE, Mitropolit al Mesoghiei și Lavreoticii, „Incinerarea morților", https://www.pemptousia.ro/2013/03/incinerarea-mortilor/ (accesat la data de 13.11.2021).

46. TEŞU, Pr. Ioan C., „Înhumarea versus incinerare”, https://doxologia.ro/puncte-de-vedere/inhumare-versus-incinerare (accesat la data de 13.11.2021). 